\title{
Bloqueio dos Nervos Ilioinguinal e Iliohipogástrico Guiado por Ultra-Sonografia Associado à Anestesia Geral. Relato de Caso*
}

\section{Ultrasound-Guided Ileoinguinal and Ileohypogastric Nerve Block Associated with General Anesthesia. Case Report}

\author{
Diogo Brüggemann da Conceição ${ }^{1}$, Pablo Escovedo Helayel, TSA ${ }^{1}$
}

\section{RESUMO}

Conceição DB, Helayel PE - Bloqueio dos Nervos llioinguinal e lliohipogástrico Guiado por Ultra-Sonografia Associado à Anestesia Geral. Relato de Caso.

JUSTIFICATIVA E OBJETIVOS: Procedimentos cirúrgicos realizados em regime ambulatorial estão se tornando mais freqüentes. $O$ bloqueio dos nervos ilioinguinal e iliohipogástrico tem sido usado para analgesia pós-operatória de pacientes submetidos à herniorrafia inguinal em regime ambulatorial. A ultra-sonografia auxilia as técnicas de anestesia regional possibilitando mais precisão no depósito do anestésico local ao redor dos nervos. O objetivo deste relato foi apresentar um caso de bloqueio dos nervos ilioinguinal e iliohipogástrico guiado por ultra-sonografia em paciente agendado para herniorrafia inguinal em regime ambulatorial.

RELATO DO CASO: Paciente do sexo masculino, 36 anos, $74 \mathrm{~kg}$, estado físico ASA I, agendado para realização de herniorrafia inguinal. Foi realizado o bloqueio dos nervos ilioipogástrico e ilioinguinal guiado por ultra-sonografia com ropivacaína a 0,5\% e, em seguida, realizada anestesia venosa total. O paciente recebeu alta hospitalar quatro horas após o procedimento com escore de dor avaliado pela Escala Analógica Verbal de 3.

CONCLUSÕES: O bloqueio dos nervos iliohipogástrico e ilioinguinal guiado por ultra-sonografia em pacientes submetidos à herniorrafia inguinal em regime ambulatorial pode ser utilizado no auxílio do controle da dor pós-operatória.

Unitermos: CIRURGIA, Geral: herniorrafia inguinal; TÉCNICAS ANESTÉSICAS, Regional: bloqueio ilioinguinal, bloqueio iliohipogástrico.

\footnotetext{
${ }^{*}$ Recebido do (Received from) Núcleo de Ensino e Pesquisa em Anestesia Regional do Hospital Governador Celso Ramos (HGCR), CET Integrado de Anestesiologia da SES-SC, Florianópolis, SC

1. Anestesiologista do CET Integrado de Anestesiologia da SES-SC; Membro do Núcleo de Ensino e Pesquisa em Anestesia Regional do HGCR

Apresentado (Submitted) em 9 de novembro de 2006

Aceito (Accepted) para publicação em 24 de setembro de 2007

Endereço para correspondência (Correspondence to):

Dr. Diogo Brüggemann da Conceição

Rua Bocaiúva, 1.659/1.103

88015-530 Florianópolis, SC

E-mail:diconceicao@hotmail.com

(C) Sociedade Brasileira de Anestesiologia, 2007
}

\section{SUMMARY}

Conceição DB, Helayel PE — Ultrasound-guided Ilioinguinal and Iliohypogastric Nerve Block Associated with General Anesthesia. Case Report.

BACKGROUND AND OBJECTIVES: Outpatient surgeries are becoming more frequent. llioinguinal and iliohypogastric nerve block has been used in postoperative analgesia of patients undergoing outpatient inguinal herniorrhaphy. Ultrasound-guided regional anesthesia increases the accuracy of deposition of the local anesthetic around the nerves. The objective of this report was to present a case of ultrasound-guided ilioinguinal and iliohypogastric nerve block for outpatient inguinal herniorrhaphy.

CASE REPORT: A 36-year old male patient, $74 \mathrm{~kg}$, physical status ASA I, was scheduled for inguinal herniorrhaphy. Ultrasound-guided iliohypogastric and ilioinguinal nerve block was accomplished with $0.5 \%$ ropivacaine, followed by total intravenous anesthesia. The patient was discharged from the hospital 4 hours after the procedure with a pain score of 3 in the Verbal Analogue Scale.

CONCLUSION: Ultrasound-guided iliohypogastric and ilioinguinal nerve block in patients undergoing outpatient inguinal herniorrhaphy can be done as an aid to postoperative analgesia.

Key Words: ANESTHETIC TECHNIQUES, Regional: ilioinguinal nerve block, iliohypogastric nerve block; SURGERY, General: inguinal herniorrhaphy.

\section{INTRODUÇÃO}

Os procedimentos cirúrgicos realizados em regime ambulatorial estão se tornando mais freqüentes em virtude do desenvolvimento de técnicas cirúrgicas menos invasivas, da melhora no controle da dor pós-operatória e da necessidade de diminuição de custos ${ }^{1}$.

O bloqueio dos nervos ilioinguinal (II) e iliohipogástrico (IH) tem sido usado para auxiliar a analgesia pós-operatória e a alta precoce do paciente submetido à herniorrafia inguinal em regime ambulatorial.

A maioria das técnicas descritas para o bloqueio desses nervos é realizada com base em referências anatômicas através de cliques fasciais com falhas superiores a $20 \%$ na população pediátrica ${ }^{2}$. O desenvolvimento de transdutores para ultra-sonografia de alta freqüência tornou possível a visualização de nervos superficiais ${ }^{3}$. Recentemente, foi 
descrita técnica para bloqueio seletivo dos nervos II e IH guiado por ultra-sonografia ${ }^{4}$.

O objetivo deste trabalho foi relatar bloqueio dos nervos ilioinguinal e iliohipogástrico guiado por ultra-sonografia em um paciente agendado para herniorrafia inguinal em regime ambulatorial.

\section{RELATO DO CASO}

Paciente do sexo masculino, 36 anos, $74 \mathrm{~kg}, 1,75 \mathrm{~m}$, estado físico ASA I, agendado para herniorrafia inguinal direita.

Após a instalação de monitoração (cardioscópio, pressão arterial não-invasiva e oxímetro de pulso) e sedação com midazolam $\left(0,05 \mathrm{mg} \cdot \mathrm{kg}^{-1}\right)$ foi realizado bloqueio dos nervos II e IH guiado por ultra-sonografia, como descrito por Eichenberger e col. ${ }^{4}$.

Para a sua realização foi utilizado um aparelho de ultra-sonografia convencional (Sonoace 8000 SE - Medsom) com um transdutor linear de $4 \mathrm{~cm}$ banda larga (7-12 MHz).

Com o paciente em decúbito dorsal, o transdutor foi posicionado cerca de $5 \mathrm{~cm}$ acima da espinha ilíaca ânterosuperior direita em leve rotação de um plano transversal para oblíquo (Figura 1), de modo que ficasse perpendicular ao trajeto anatômico dos nervos. A parte lateral do transdutor ficou sobre a crista ilíaca. Após a localização de ambos os nervos entre os músculos oblíquo interno e transverso do abdome (Figura 2), foi inserida agulha não-cortante de $5 \mathrm{~cm}$ (Plexufix - B-Braun) transversalmente ao transdutor e injetados $10 \mathrm{~mL}$ de ropivacaína a $0,5 \%$ em cada nervo. Após 15 minutos avaliou-se a sensibilidade cutânea na região da incisão pelo teste com ponta de agulha $27 \mathrm{G}$, no qual o paciente referiu parestesia.

A anestesia cirúrgica foi realizada com infusão-alvo controlada de propofol (Diprifusor - Astra Zeneca) e alfentanil $20 \mu \mathrm{g} \cdot \mathrm{kg}^{-1}$. Para a manutenção da via aérea foi utilizada más-

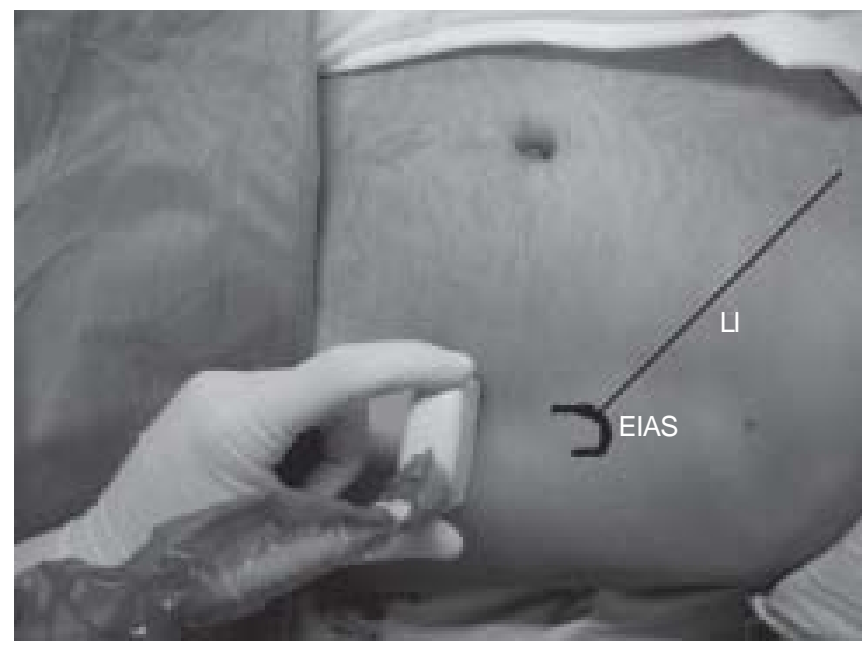

Figura 1 - Posicionamento do Transdutor. EIAS = espinha ilíaca ântero-superior; $\mathrm{LI}=$ ligamento inguinal.

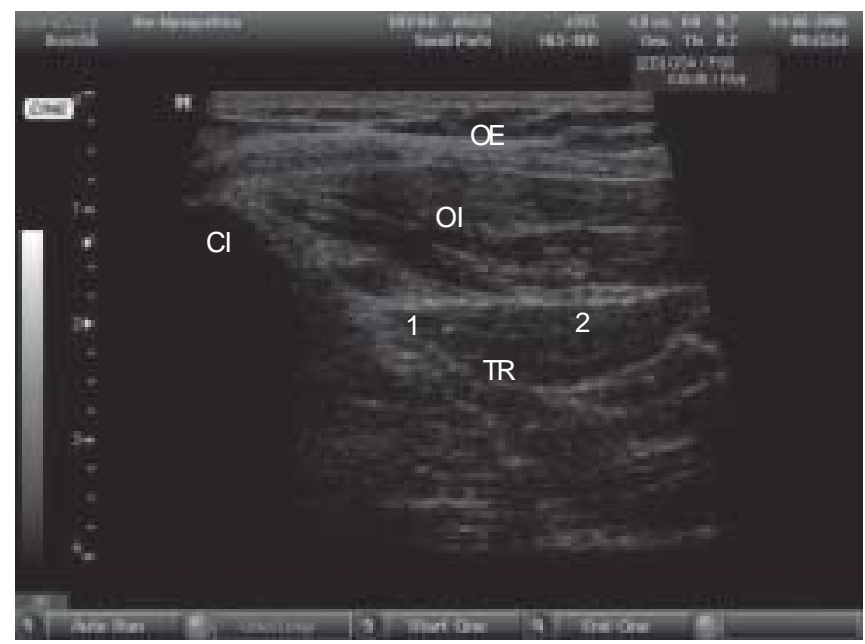

Figura 2 - Imagem Ultra-sonográfica Obtida com o Transdutor Posicionado. $\mathrm{Cl}$ = crista ilíaca; $\mathrm{OE}$ = músculo oblíquo externo; $\mathrm{OI}=$ músculo oblíquo interno; $\mathrm{TR}=$ músculo transverso do abdome; 1 = nervo ileoinguinal; 2 = nervo ileohipogástrico.

cara laríngea número 4 e ventilação controlada ciclada a pressão. Foram administrados $40 \mathrm{mg}$ de tenoxicam por via venosa 20 minutos antes do término do procedimento.

A analgesia foi avaliada a cada 30 minutos pela Escala Analógica Verbal. O paciente recebeu alta hospitalar quatro horas após o término do procedimento com VAS de 3 . Nenhum outro analgésico foi administrado.

\section{DISCUSSÃO}

Um dos critérios de alta para pacientes em regime ambulatorial é o controle adequado da dor pós-operatória. O uso da anestesia regional é uma das formas empregadas para esse fim. O bloqueio dos nervos II e IH é muito utilizado para analgesia pós-operatória em pacientes pediátricos com bons resultados ${ }^{2}$. Seu uso em pacientes adultos vem crescendo em decorrência do aumento de herniorrafia inguinal realizada em regime ambulatorial ${ }^{5}$.

As técnicas habitualmente utilizadas para esses bloqueios são realizadas com base em referências anatômicas, por meio de cliques fasciais, utilizando grandes volumes de anestésico local e são relativamente não-seletivas ${ }^{5}$, tendo como conseqüência falhas superiores a $20 \%$ em pacientes pediátricos ${ }^{2}$.

O uso da ultra-sonografia no auxílio aos bloqueios periféricos vem aumentando ${ }^{3}$. Ela permite a visualização direta de nervos, a detecção de variações anatômicas e evita lesões a estruturas adjacentes ao nervo ${ }^{3}$.

A técnica utilizada para o bloqueio dos nervos $\mathrm{II}$ e $\mathrm{IH}^{4}$ permite o bloqueio seletivo de cada um dos nervos. O local de injeção, cerca de $5 \mathrm{~cm}$ acima da espinha ilíaca ântero-superior, permite uma fácil orientação ultra-sonográfica, pois nesse ponto todas as três camadas musculares da pare- 
de abdominal estão presentes ${ }^{6}$ e podem ser visualizadas. Os nervos $\mathrm{II}$ e $\mathrm{IH}$ em $95 \%$ dos casos, nesse ponto, se encontram entre os músculos oblíquo interno e transverso do abdome ${ }^{4}$.

Concluindo, o bloqueio seletivo dos nervos ilioinguinal e iliohipogástrico possibilitou, nesse caso, boa qualidade de analgesia e a alta precoce do paciente. $\mathrm{O}$ uso da ultra-sonografia no auxílio de técnicas para anestesia regional promove mais precisão na deposição do anestésico local, levando a maior segurança para o paciente e para o anestesiologista.

\section{Ultrasound-Guided Ileoinguinal and Ileohypogastric Nerve Block Associated with General Anesthesia. Case Report}

\author{
Diogo Brüggemann da Conceição, M.D.; Pablo Escovedo \\ Helayel, TSA, M.D.
}

\section{INTRODUCTION}

Outpatient surgeries are becoming more frequent due to the development of less invasive surgical techniques, better control of postoperative pain and the need to decrease costs ${ }^{1}$. llioinguinal (II) and iliohypogastric (IH) nerve block has been used as an aid to postoperative analgesia and for early hospital discharge of patients undergoing outpatient inguinal herniorrhaphy.

Most techniques described for the blockade of those nerves are carried out based on anatomical references through fascial clicks, with a failure rate above $20 \%$ in the pediatric population ${ }^{2}$.

The development of high-frequency ultrasound transducers made it possible the visualization of superficial nerves ${ }^{3}$. Recently, an ultrasound-guided selective block of the II and $\mathrm{IH}$ nerves has been described ${ }^{4}$.

The objective of this study was to report a case of ultrasound-guided ilioinguinal and iliohypogastric nerve block in a patient scheduled for outpatient inguinal herniorrhaphy.

\section{CASE REPORT}

A 36-year old male patient, weighing $74 \mathrm{~kg}$, with $1.75 \mathrm{~m}$, physical status ASA I, scheduled for right inguinal herniorrhaphy.

After monitoring (cardioscope, non-invasive blood pressure and pulse oximetry) and sedation with midazolam (0.05 $\left.\mathrm{mg} \cdot \mathrm{kg}^{-1}\right)$, an ultrasound-guided $\mathrm{II}$ and $\mathrm{IH}$ nerve block as described by Eichenberger et al. ${ }^{4}$ was performed.

A conventional ultrasound equipment (Sonoace $8000 \mathrm{SE}-$ Medsom) with a 4-cm broad band (7-12 MHz) linear transducer was used.
With the patient in dorsal decubitus, the transducer was placed approximately $5 \mathrm{~cm}$ above the right anterior superior iliac spine in a slight rotation, from a transversal to oblique plane (Figure 1) in order to remain perpendicular to the anatomic path of the nerves. The lateral portion of the transducer was over the iliac crest. After localizing both nerves between the internal oblique and transverse abdominis muscles ( $\mathrm{Fi}$ gure 2), a $5 \mathrm{~cm}$ non-cutting needle (Plexufix - B-Braun) was introduced transversely to the transducer and $10 \mathrm{~mL}$ of $0.5 \%$ ropivacaine were injected on each nerve. After 15 minutes, cutaneous sensitivity in the area of the incision was tested with a $27 \mathrm{G}$ needle and the patient referred paresthesia.

For the surgical anesthesia, a target-controlled infusion of propofol (Diprifusor - Astra Zeneca) and alfentanil $20 \mu \mathrm{g} \cdot \mathrm{kg}^{-1}$

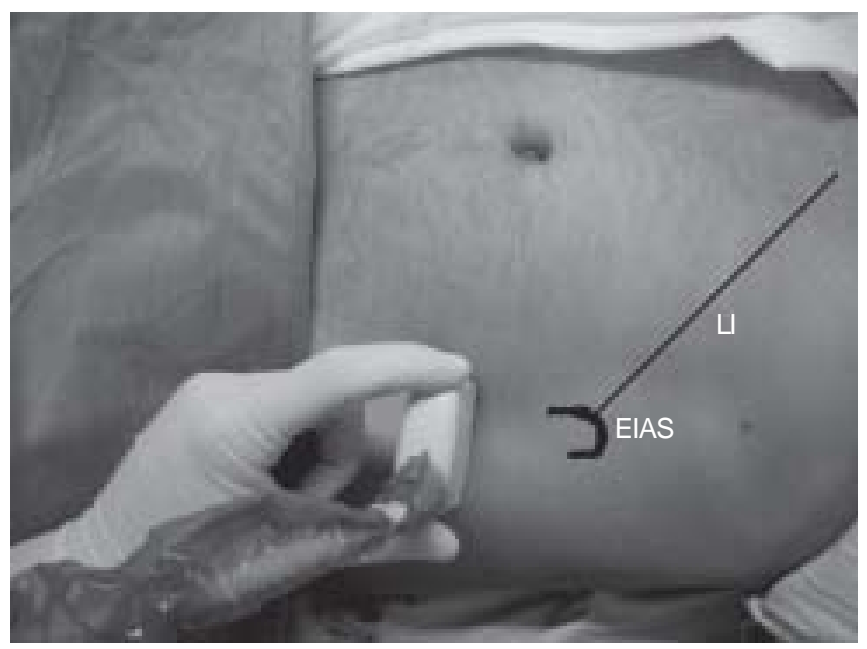

Figure 1 - Transducer Positioning. EIAS = antero-superior iliac spine; $\mathrm{LI}=$ inguinal ligament.

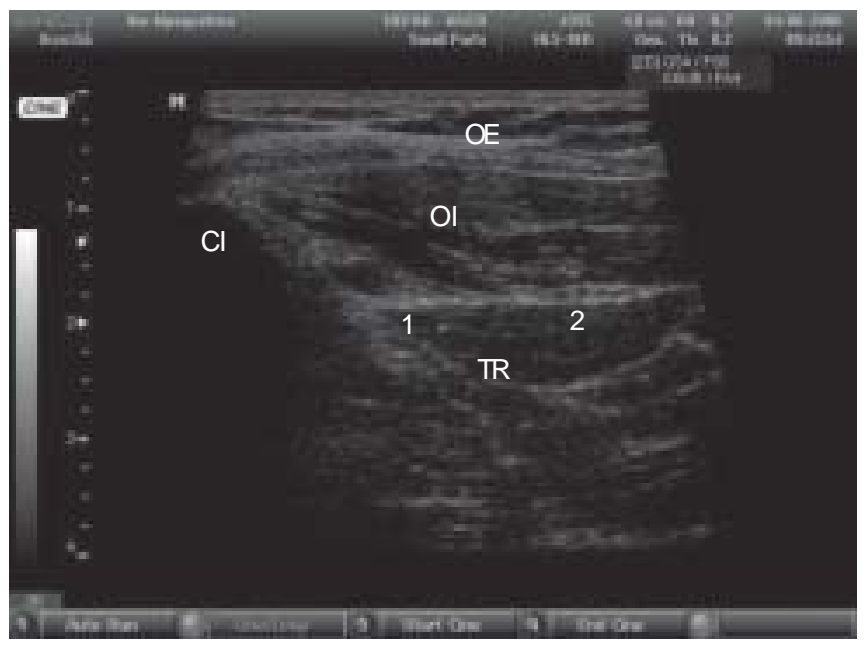

Figure 2 - Ultrasound Image Obtained when the Transducer is Positioned. $\mathrm{Cl}$ = iliac crest; $\mathrm{OE}=$ externa oblique muscle; OI = internal oblique muscle; TR = transverse abdominis muscle; $1=$ ilioinguinal nerve; 2 = iliohypogastric nerve. 
were used. A number 4 laryngeal mask and pressure-controlled ventilation were used to maintain the airways opened. Forty milligrams of intravenous tenoxicam were administered 20 minutes before the end of the surgery.

Analgesia was evaluated every 30 minutes using the Verbal Analogue Scale. The patient was discharged from the hospital four hours after the surgery with a VAS score of 3 . The patient did not receive any other analgesics.

\section{DISCUSSION}

Adequate control of postoperative pain is one of the criteria for discharging patients after outpatient surgery. Regional blocks are used for this ending. Ilioinguinal and iliohypogastric nerve block is frequently used for postoperative analgesia in pediatric patients with good results ${ }^{2}$. Its use in adult patients has been increasing due to a higher incidence of outpatient inguinal herniorrhaphy ${ }^{5}$.

The techniques used most often for those blocks are based on anatomical references, through fascial clicks, injecting large volumes of local anesthetic and are relatively nonselective ${ }^{5}$ and consequently carry a failure rate above $20 \%$ in pediatric patients ${ }^{2}$.

The use of ultrasound-guided peripheral nerve blocks has been rising ${ }^{3}$. It allows direct visualization of the nerves, detection of anatomical variations and prevents damaging structures adjacent to the nerves ${ }^{3}$.

The technique used for the $\mathrm{II}$ and $\mathrm{IH}^{4}$ nerve block allows the selective blockade of each one of the nerves. The local of injection, approximately $5 \mathrm{~cm}$ above the antero-superior iliac spine, facilitates ultrasound orientation since at this point all three muscle layers of the abdominal wall are present ${ }^{6}$ and can be visualized. In $95 \%$ of the cases, the $\mathrm{II}$ and $\mathrm{IH}$ nerves, at this point, are between the internal oblique and abdominis transverse muscles ${ }^{4}$.

To conclude, the selective of the ilioinguinal and iliohypogastric nerves block provided, in this case, good quality analgesia and early discharge of the patient. The use of ultrasound as an aid to regional anesthesia promotes higher precision of local anesthetic deposition, increasing safety, both for the patient and the anesthesiologist.

\section{REFERÊNCIAS - REFERENCES}

01. Cangiani LM - Anestesia Ambulatorial: Conceito e Aspectos Gerais, em: Cangiani LM - Anestesia Ambulatorial. São Paulo, Atheneu, 2001;3-26.

02. Lim SL, Ng Sb A, Tan GM — llioinguinal and iliohypogastric nerve block revisited: single shot versus double shot technique for hernia repair in children. Paediatr Anaesth, 2002;12:255-260.

03. Marhofer P, Greher M, Kapral S - Ultrasound guidance in regional anesthesia. Br J Anaesth, 2005;94:7-17.

04. Eichenberger U, Greher M, Kirchmair L et al. — Ultrasound-guided blocks of the ilioinguinal and iliohypogastric nerve: accuracy of a selective new technique confirmed by anatomical dissection. $\mathrm{Br} J$ Anaesth, 2006;97:238-243.

05. Toivonen J, Permi J, Rosenberg PH - Effect of preincisional ilioinguinal and iliohypogastric nerve block on postoperative analgesic requirement in day-surgery patients undergoing herniorrhaphy under spinal anaesthesia. Acta Anaesthesiol Scand, 2001;45:603-607.

06. Gardner E - Nervos do Abdome, em: Gardner E, Gray DJ, O'Rahilly — Anatomia: Estudo Regional do Corpo Humano. $2^{2}$ Ed, Rio de Janeiro, Guanabara Koogan, 1967;487-493.

\section{RESUMEN}

Conceição DB, Helayel PE - Bloqueo de los Nervios ĺleoinguinal e Íleohipogástrico Guiado por Ultrasonografía Asociado a Anestesia General. Relato de Caso.

JUSTIFICATIVA Y OBJETIVOS: Procedimientos quirúrgicos realizados en régimen ambulatorial se están convirtiendo cada vez más frecuentes. El bloqueo de los nervios íleoinguinal e íleohipogástrico ha sido usado para la analgesia postoperatoria de pacientes sometidos a la herniorrafia inguinal en régimen ambulatorial. La ultrasonografía auxilia las técnicas de anestesia regional posibilitando una mayor precisión en el depósito del anestésico local el rededor de los nervios. El objetivo de este relato fue presentar un caso de bloqueo de los nervios íleoinguinal e íleohipogástrico guiado por ultrasonografía en paciente a realizar herniorrafia inguinal en régimen ambulatorial.

RELATO DEL CASO: Paciente del sexo masculino, 36 años, 74 $\mathrm{kg}$, estado físico ASA I, listo para la realización de herniorrafia inguinal. Fue realizado el bloqueo de los nervios íleohipogástrico e íleoinguinal guiado por ultrasonografía con ropivacaína a 0,5\% y enseguida fue realizada anestesia venosa total. El paciente tuvo alta 4 horas después del procedimiento con puntuación de dolor evaluado por la Escala Analógica Verbal de 3.

CONCLUSIONES: El bloqueo de los nervios íleohipogástrico e íleoinguinal guiados por ultrasonografía en pacientes sometidos a herniorrafia inguinal en régimen ambulatorial, puede ser utilizado en el auxilio del control del dolor postoperatorio. 